\title{
ÆUSGS
}

science for a changing world

\section{Geologic Map of the Valley Mountain 15' Quadrangle, San Bernardino and Riverside Counties, California}

Pamphlet to accompany

Geologic Quadrangle Map GQ-1767

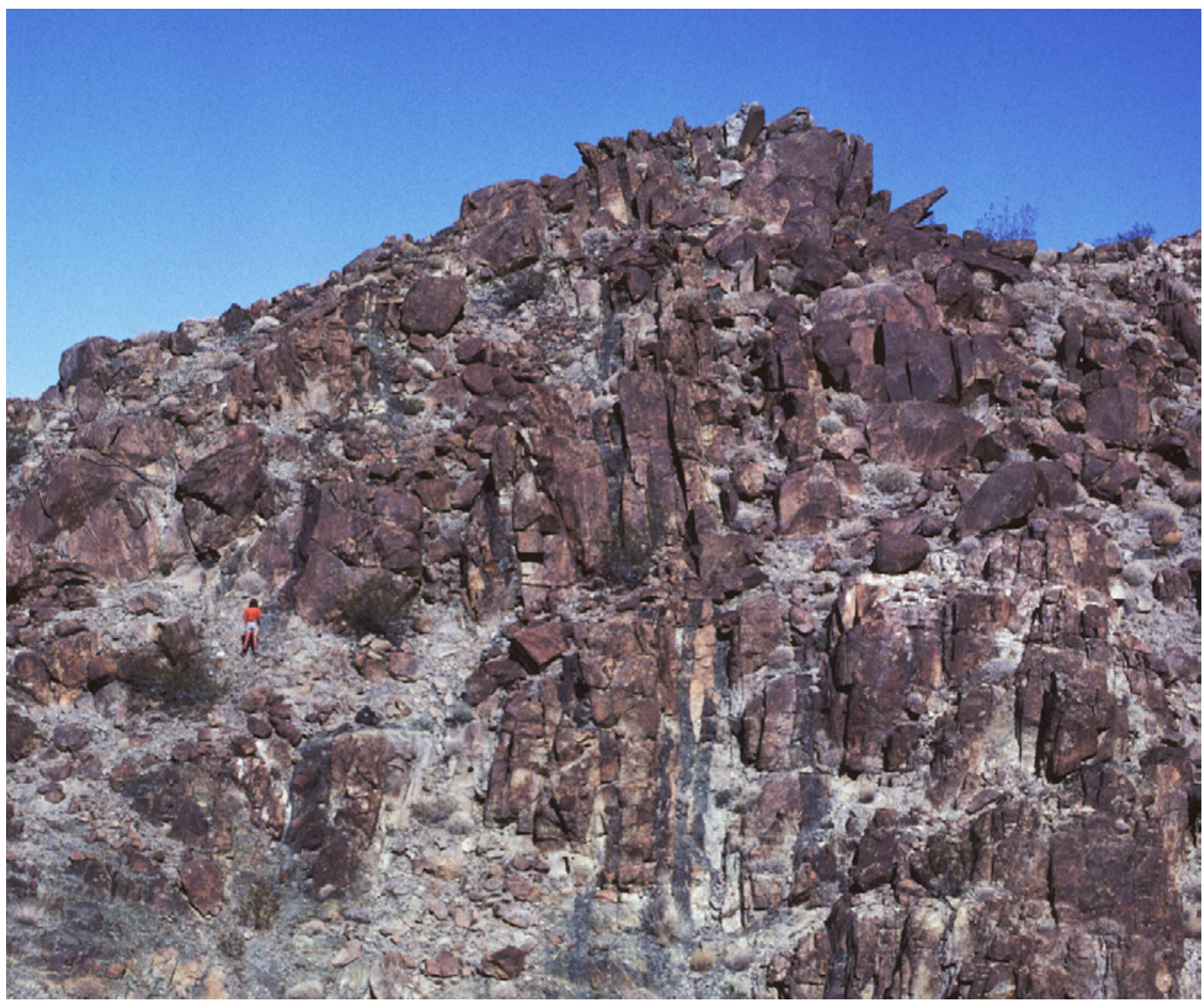

Jurassic rocks in the Pinto Mountains. Virginia Dale Quartz Monzonite and dark, steeply dipping mafic dikes. Near the Marbolite Mine, $6 \mathrm{~km}$ east of Twentynine Palms Mountain. Photo by Lisanne Pearcy. 


\section{Contents}

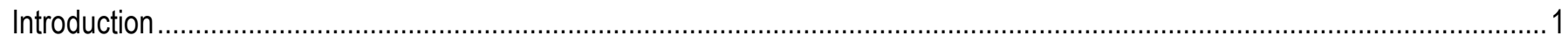

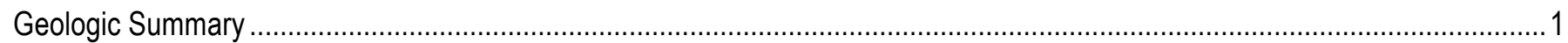

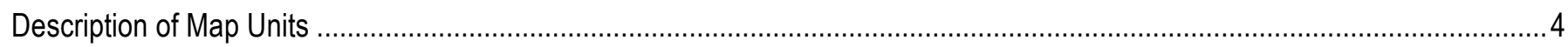

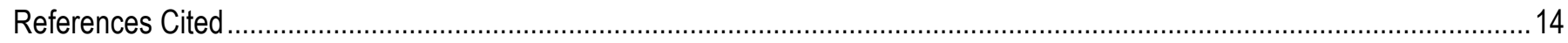

\section{Figures}

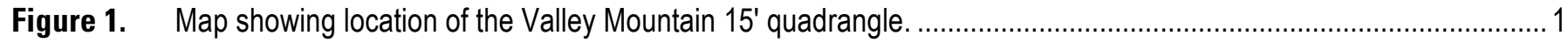

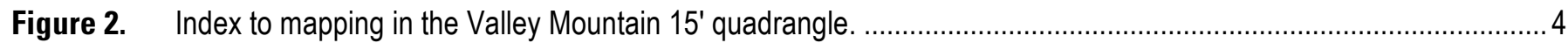

Figure 3. Modal compositions of plutonic rocks in the Valley Mountain 15' quadrangle, based on counts on stained slabs. Powell (1981) listed modal counts for the granite of Joshua Tree (Xjt)...... 


\section{Geologic Map of the Valley Mountain 15' Quadrangle, San Bernardino and Riverside Counties, California}

By Keith A. Howard, John Bacheller1', Todd T. Fitzgibbon, Robert E. Powell, and Charlotte M. Allen

\section{Introduction}

The Valley Mountain quadrangle straddles the physiographic boundary between the eastern Transverse Ranges on the south and the central Mojave Desert on the north (fig. 1; Howard, 2002). The Pinto Mountains in the southern part of the quadrangle form the northernmost of the eastern Transverse Ranges. Rocks in the quadrangle record Proterozoic, Mesozoic, and late Cenozoic events. Geographic Information System and metadata on most geologic features (except some subunits and small polygons) are available on Geologic map of the Sheep Hole Mountains 30' x 60' quadrangle, San Bernardino and Riverside Counties, California (Howard, 2002) at http://pubs.usgs.gov/mf/2002/2344/.

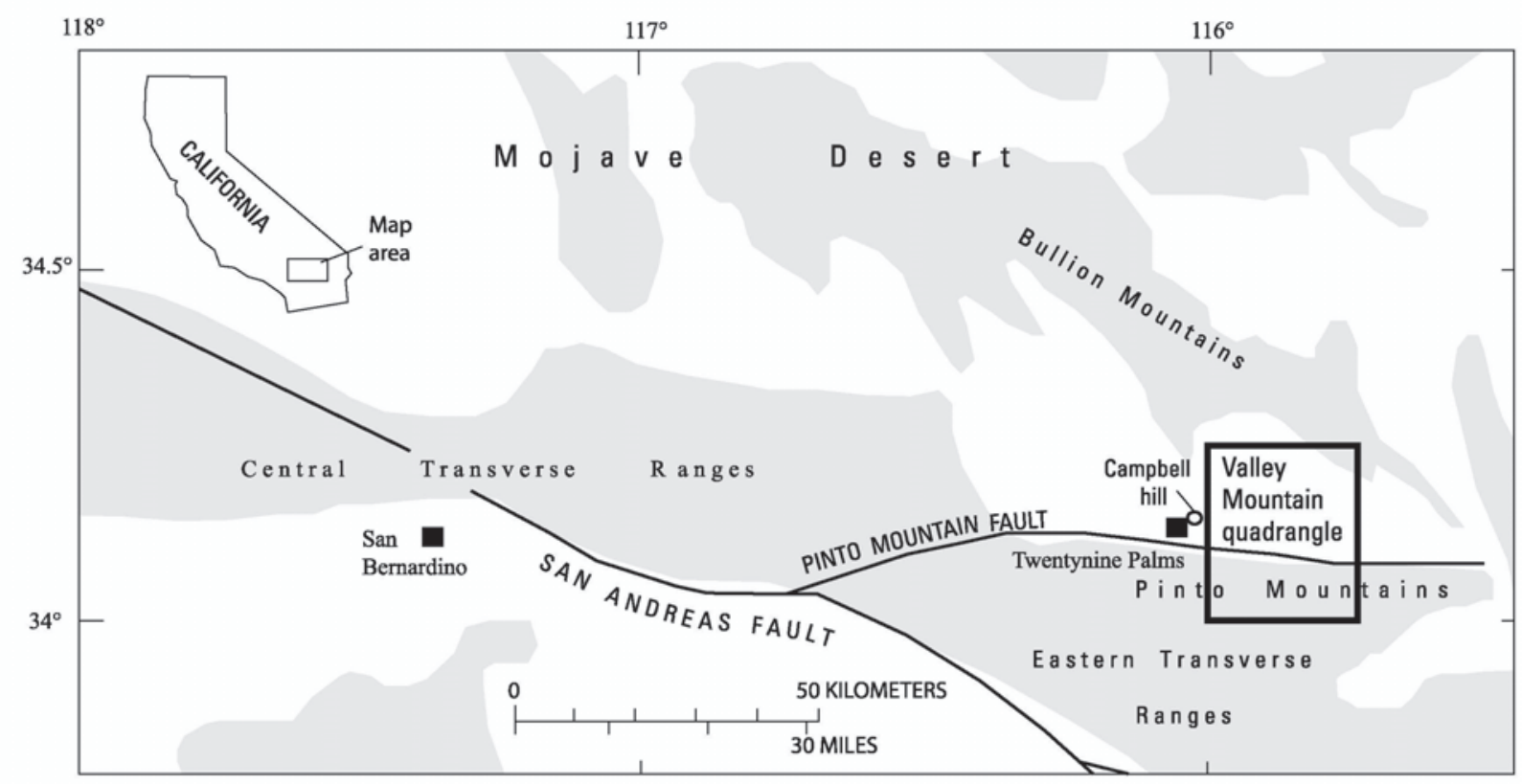

Figure 1. Map showing location of the Valley Mountain 15' quadrangle.

\section{Geologic Summary}

The Paleoproterozoic Dog Wash Gneiss cuts older diorite and amphibolite as well as the Pinto Gneiss of Miller (1938). The Dog Wash Gneiss and these older rock units were deformed and metamorphosed together, and a unit of spotted gneiss present in the quadrangle may be a granulite-facies rock type metamorphosed from one or more of these protoliths and subsequently retrograded to

${ }^{1}$ Department of Earth and Space Sciences, University of California, Los Angeles 
amphibolite facies. Plutonism and metamorphism may be related to 1.7-Ga metamorphism and plutonism described as the Ivanpah orogeny from the northern Mojave Desert (Wooden and Miller, 1990).

Powell $(1981,1982)$ proposed that metasedimentary granofels of the Pinto Gneiss of Miller (1938) interfingers and correlates with the quartzite of Pinto Mountain, which overlies the Paleoproterozoic granite of Joshua Tree. This proposed correlation may conflict with undocumented U$\mathrm{Pb}$ zircon ages reported to be $\geq 1.68 \mathrm{Ga}$ for the Dog Wash Gneiss and $\geq 1.65 \mathrm{Ga}$ for the granite of Joshua Tree.

An early Mesozoic deformational event is suggested by the deformed nature of the quartz monzonite of Twentynine Palms as contrasted with younger undeformed Jurassic and Late Cretaceous igneous rocks nearby. The quartz monzonite of Twentynine Palms ( $\mathrm{kt}$ ) is assigned an Early Triassic age based on U-Pb dating and similarity to other Triassic rocks (Barth and others, 1997). The unit resembles in texture a 215-Ma megaporphyritic monzogranite described by Frizzell and others (1986) and parts of the approximately 218-Ma Mount Lowe intrusion (Barth and others, 1990), both in the central Transverse Ranges. The quartz monzonite of Twentynine Palms shows evidence of metamorphism and ductile deformation prior to intrusion of nonlineated (but locally foliated) Jurassic rocks of the nearby Music Valley and Goat Basin Plutons: K-feldspar phenocrysts in the quartz monzonite of Twentynine Palms are commonly deformed and recrystallized as highly flattened, elongate, crystal aggregates. Eastnortheast-striking mylonitic stretching lineation, gently dipping foliation, and westward-overturned folds in this unit and in host Proterozoic gneiss units suggest that major deformation occurred during the early Mesozoic. Similarly oriented structures $20-50 \mathrm{~km}$ to the south were related to a proposed Red Cloud thrust system of composite Paleoproterozoic and post-Mesoproterozoic age (Postlethwaite, 1988).

Jurassic rocks include diorite bodies $(\mathrm{Jd})$ and several bodies of younger more felsic rocks, including a batholith of porphyritic quartz monzonite and related rocks. Granodiorites in both the Music Valley and Goat Basin Plutons (Jm, Jgb units) near the southwest corner of the quadrangle contain euhedral epidote of probable magmatic origin that is considered a geobarometric indicator of mid-crustal or deeper emplacement. Jurassic rocks in the southeastern and northern parts of the quadrangle form part of a batholith dominated by quartz monzonite (Bullion Mountains Intrusive Suite) and also include a thin unit of limestone (Jl) and extrusive volcanic and hypabyssal rocks (Jvh) emplaced at and near the surface. The deep emplacement level of Jurassic plutons in the southwest in contrast to volcanic rocks and limestone in the east indicates that large structural relief and differential uplift developed across the quadrangle since the Jurassic.

Swarms of north- to north-northwest-striking mafic and felsic dikes (Jmd, Jgp, Jdu) cut the Jurassic plutonic rocks and are inferred to correlate with the Late Jurassic Independence Dike Swarm (James, 1989; Hopson and others, 2008). These dikes in turn are cut by Late Cretaceous microgranite dikes (Kf) in the south-central part of the quadrangle. The Late Cretaceous Cadiz Valley Batholith is represented in the northeast corner of the quadrangle by the Sheep Hole Pass Granite (Howard and John, 1984; Howard, 2002). A metamorphic aureole in Jurassic country rocks fringes this granite body.

A post-Jurassic, east-dipping, low-angle normal fault system at the southeast end of Twentynine Palms Mountain appears to juxtapose rocks formed at different crustal levels and account for some of the structural relief across the quadrangle. The deep-seated epidote-bearing Jurassic plutons reside in the footwall of this fault system. The normal fault system is expressed by a topographically low chloritic zone 500-1,000 $\mathrm{m}$ wide in which microdiorite dikes are displaced down to the west on unmapped, small-displacement, gently west-dipping faults. The fault zone is indicated on the map by a low-angle normal fault arbitrarily drawn at the base of the chloritic disrupted zone. The chloritic zone of normal faults truncates abruptly eastward against a younger steep north-northwest-striking fault (part of a system of faults that project toward the Twentynine Palms Mountain Fault); east of the fault, dissimilar 
rock types are exposed. The chloritic zone of normal faulting resembles zones that underlie major Tertiary low-angle normal faults elsewhere in southeastern California (for example, the Whipple Mountains Detachment Fault). Our cross sections interpret the zone to be dropped westward along a younger north-northwest-striking fault and to be roofed by an unexposed, potentially large-displacement low-angle normal fault that omits substantial crustal section.

Tertiary rocks in the quadrangle are the Miocene basalt of Valley Mountain (Tvm) and a Pliocene and (or) Miocene gravel unit ( $\mathrm{Tg}$ ) that caps ridges in the northeast and the southwest parts of the quadrangle. Late Miocene basalt flows $5 \mathrm{~km}$ southeast of the quadrangle have yielded paleomagnetic declinations interpreted as rotated about $42^{\circ}$ clockwise and have been interpreted to indicate Cenozoic tectonic rotation of the Pinto Mountains relative to the Mojave Desert to the north (Carter and others, 1987). Jurassic dikes in the Pinto Mountains, however, are nearly aligned with those at Valley Mountain and in the Bullion Mountains (Dibblee, 1968; Howard and others, 1995), which suggests that any relative rotation between the ranges was small (Howard and others, 1997; Hopson and others, 2008). Moreover, pre-late Cenozoic paleogeologic reconstruction of rocks in the Transverse Ranges and Mojave Desert can be achieved by back-rotating the eastern Transverse Ranges by only $20^{\circ}$ to $25^{\circ}$ (Powell, 1993).

Quaternary deposits and structures, described in detail by Bacheller (1978), record the most recent evolution of the complex boundary between the eastern Transverse Ranges and ranges of the central Mojave Desert. Pleistocene oldest alluvium derived from nearby mountains interfingers valleyward with the sedimentary deposits of Campbell Hill, which consist of lake beds and fluvial deposits derived from the San Bernardino Mountains to the west. Younger surficial deposits of alluvium and windblown sand were mapped largely by photogeologic techniques.

East-striking left-slip faults such as the Pinto Mountain Fault cut Quaternary deposits along the northern structural boundary of the Pinto Mountains and in other parts of the eastern Transverse Ranges (Dibblee, 1967; Hopson, 1998). Northwest-striking right-slip faults cut Quaternary deposits in the Bullion Mountains and other parts of the central Mojave Desert. The Mesquite Lake, Cleghorn Lakes, and Valley Mountain Faults in the quadrangle appear to belong to this latter set (Jagiello and others, 1992; Howard and Miller, 1992). Plutonic and metamorphic rocks are displaced 16 to $19 \mathrm{~km}$ in a sinistral sense across the Pinto Mountain Fault (Dibblee, 1967; Bacheller, 1978; Powell, 1993; Hopson, 1996). Bacheller (1978) detailed arguments for a minimum of $9 \mathrm{~km}$ of left slip of the Pleistocene oldest alluvium along the Pinto Mountain Fault System along the north front of the Pinto Mountains. His conclusion was based on the distribution of clasts derived south of the fault from the Jurassic Virginia Dale Quartz Monzonite (Jbv). South of the fault (except at its mapped east end) the oldest alluvium unit contains only gneiss clasts, reflecting the source bedrock of the adjacent front of the Pinto Mountains in the Twentynine Palms Mountain area. Bedding in the porphyritic-clast facies (Qop) of the oldest alluvium north of the fault projects southward over adjacent low outcrops of the Virginia Dale Quartz Monzonite and contains clasts of quartzite conglomerate and porphyritic quartz monzonite. These clasts were apparently derived from southerly sources now offset sinistrally to the east.

On this map, the Pinto Mountain Fault is one of a system of east-striking faults and aligned shutterridges that cross the full width of the quadrangle. The shutterridges track eastward through the site of Old Dale and beyond into the Dale Lake quadrangle and are mapped here as bordered by concealed faults. Several splays of the fault system veer southeast into the Pinto Mountains. One of these, here designated the Twentynine Palms Mountain Fault, has a reverse fault sense where it dips $70^{\circ}$ west at an east-facing scarp in older alluvium at the east foot of Twentynine Palms Mountain. This mountain is the highest in the region and may owe its height to the reverse faulting. Left-oblique reverse or thrust faulting with compression and uplift on southeastern-striking splays is compatible kinematically with the left slip along east-trending parts of the Pinto Mountain Fault Zone. Similar 
geometry marks the curved east end of the left-slip Garlock Fault at the northern border of the Mojave Desert.

Northwest-striking faults here designated the East Valley Mountain Fault and the West Valley Mountain Fault deform alluvium and form barriers to groundwater flow (Moyle, 1961). Most young faults that have this orientation in the central Mojave Desert exhibit right slip (Dibblee, 1961; Dokka and Travis, 1990). Short northeast-striking faults that abut the east Valley Mountain Fault may bound subsidiary grabens.

Cross sections show the interpreted style of deformation and distribution of rock bodies. Crosssection interpretations in alluvial areas were aided by interpretation of aeromagnetic and gravity maps (U.S. Geological Survey, 1981; Mariano and others, 1986). Geologic mapping responsibilities are shown in figure 2.)

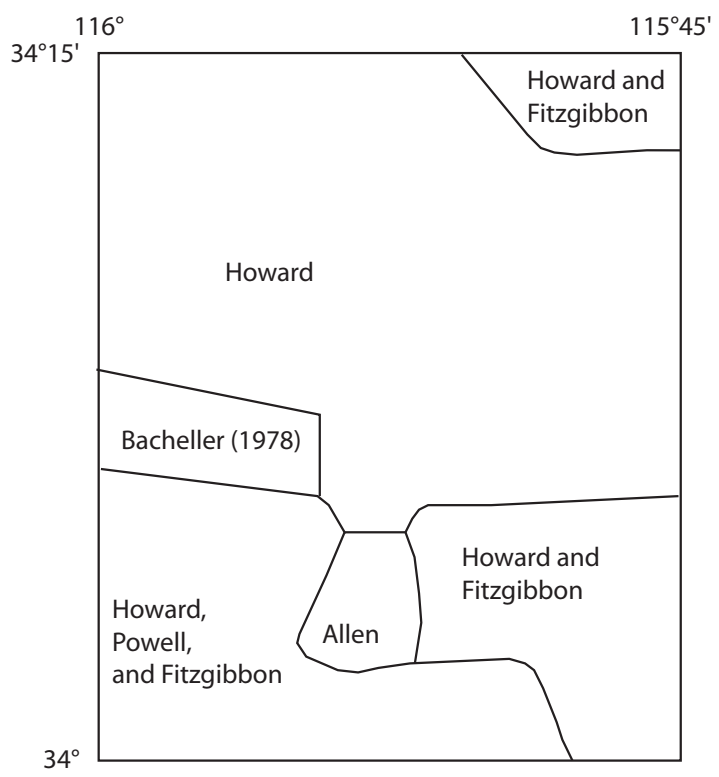

Figure 2. Index to mapping in the Valley Mountain $15^{\prime}$ quadrangle.

\section{DESCRIPTION OF MAP UNITS}

Surficial deposits (Holocene and Pleistocene)—Distinguished chiefly by photogeologic techniques based on differences in albedo, color, morphologic character, physiographic position, and amounts and types of covering vegetation

Qw Windblown sand (Holocene) - Loose fine- to medium-grained sand deposited by prevailing westerly winds as dunes and sheets over alluvium. Includes both active and stabilized sheets

Qy Youngest alluvium (Holocene) - Poorly sorted sandy gravel on floors of active washes. Clasts are angular, crystalline rocks derived from adjacent mountains

Qya Younger alluvium (Holocene) - Poorly sorted sandy gravel. Clasts are angular, crystalline rocks derived from adjacent mountains. Mostly sand in the central part of the quadrangle. Surface characterized by bars and swales, veneered in 
places by windblown sand. Faulted areas in the central part of the quadrangle include some possibly older deposits on which reddish-brown, possibly Pleistocene soils are developed (sec. 14, T. 1 N., R. 10 E.)

Qoa Older alluvium (Pleistocene) - Sandy gravel of angular clasts. Clasts are crystalline rocks derived from adjacent mountains. Forms partly dissected fans, benches, and terraces commonly capped by dark pavement of varnished stones

Qoaq Quartzite-clast alluvium - Formed dominantly of clasts derived from the quartzite of Pinto Mountain

Qo Oldest alluvium (Pleistocene)-Forms dissected hills. Lithologically resembles the other alluvium units (Qy, Qya, Qoa, Qoaq) but is older. Commonly faulted and tilted

Qoq

Qop

Quartzite-clast facies - Present along the south-central edge of the quadrangle. Clasts are derived from the quartzite of Pinto Mountain

Porphyritic-clast facies-Present in the west-central part of the quadrangle north of the Pinto Mountain Fault. Clasts are porphyritic granitoid largely or partly derived from the Virginia Dale Quartz Monzonite (Jbv), which is absent from the adjacent Pinto Mountains front. Clasts also include conglomeratic quartzite derived from the quartzite of Pinto Mountain. Bedding in the unit projects over adjacent low exposures of the Virginia Dale Quartz Monzonite, indicating offset sources in the Pinto Mountains. Locally interfingers with the sandstone unit (Qss)

Gneiss-clast facies-Present in the west-central part of the quadrangle, mostly south of the Pinto Mountain Fault. Clasts are gneiss derived locally from the adjacent Pinto Mountains. Contains no clasts of the Virginia Dale Quartz Monzonite (Jbv). Locally interfingers with the sandstone unit (Qss). Equivalent to the mixed fanglomerate member of the Twentynine Palms unit of Bacheller (1978)

Qob Facies in the Bullion Mountains - Clasts are Mesozoic granitoid rocks locally derived from the Bullion Mountains. Consists of sandy gravel and interfingering coarse white sand and grit. Gravel includes bouldery channel fills, well-bedded cobble gravel, and massive, poorly sorted boulder conglomerate. Eroded to ridge and ravine topography. Lag boulders are present on the surface. Studied by J.R. Davis (written commun., 1980)

Qbr Sedimentary breccia (Pleistocene) - Interfingers with the oldest alluvium unit and the sandstone unit. Interpreted as landslide deposits

Qss Sandstone (Pleistocene) - Poorly indurated arkosic sandstone in lowlands adjacent to the Pinto Mountains in the southwest part of the map area and adjacent to the Bullion Mountains in the northeast part of the map area. Interfingers with subunits of the oldest alluvium at more than one stratigraphic level

South of the Pinto Mountain Fault includes green sandstone west of Dog Wash (equivalent to greenish sand member of the Twentynine Palms unit of Bacheller, 1978) and locally gypsiferous red-brown sandstone west of Dog Wash (equivalent to reddish sand member of the Twentynine Palms unit of Bacheller, 1978); both sandstones interfinger with or underlie the gneiss-clast facies (Qog) of the oldest alluvium unit. The green sandstone is as much as 
$120 \mathrm{~m}$ thick and locally is in buttress unconformity against pre-Cenozoic rocks; the green sandstone is clayey and silty (lacustrine) in its lower parts, is gravelly in its upper parts, grades upward into the gneiss-clast facies of the oldest alluvium unit, and contains a bed of ash as much as $4 \mathrm{~m}$ thick, $90 \mathrm{~m}$ below its top, that was correlated by trace-element content with the 0.7 -Ma Bishop Tuff (Bacheller, 1978). The ash is present in small mapped and unmapped outcrops of the unit in sec. 1, T. 1 S., R. 9 E.; it is best exposed in the E1/2 NE1/4 NW1/4 NW1/4 of sec. 1

North of the Pinto Mountain Fault at the west edge of the quadrangle, the sandstone unit includes red-brown sandstone that rests on weathered exposures of the Virginia Dale Quartz Monzonite (Jbv) and interfingers with the sedimentary breccia unit (Qbr). In the same area, the sandstone unit includes massive sandstone at least $18 \mathrm{~m}$ thick (equivalent to massive sand member of the Twentynine Palms unit of Bacheller, 1978) that overlies the sedimentary deposits of Campbell Hill (Qch). In the northeast part of the quadrangle, a small exposure of massive brown arkosic sandstone is present adjacent to steep mountain fronts and locally rests on $0.3 \mathrm{~m}$ of basal clay

Qch Sedimentary deposits of Campbell Hill (Pleistocene) - Yellowish-gray, grayishorange, olive-gray, and yellowish-orange fluvial and lacustrine beds containing basalt, granite, marble, and quartzite clasts derived from the San Bernardino Mountains west of the quadrangle. Moderately to poorly indurated sand, bedded clast-supported gravel, silt, marl, clay, and minor fanglomerate. Grains mostly subrounded. At least $370 \mathrm{~m}$ thick. Interfingers with the oldest alluvium unit and is overlain by the sandstone unit. A Rancholabrean fauna that has yielded at least 45 vertebrate fossil parts is present in the unit $3 \mathrm{~km}$ west of the quadrangle, on Campbell Hill, about 73 m below the overlying arkosic sand unit (Bassett and Kupfer, 1964; Bacheller, 1978). Deposits were previously mapped as continental deposits by Moyle (1961), as Pleistocene(?) sediments of Twentynine Palms and the Pinto Basin by Bassett and Kupfer (1964), as older gravel and sand by Dibblee (1968), and referred to as the Campbell Hill unit by Bacheller (1978). Outcrops at Old Dale in the eastcentral part of the quadrangle consist of moderately indurated, laminated, gray-brown, greenish, and pinkish clayey and silty sandstone

Tg Gravel (Pliocene and (or) Miocene) — Caps bedrock ridges and contains clasts derived from distant, now-isolated sources. In the southwest part of the quadrangle, caliche-cemented conglomerate caps a flat mountain at elevations of 3,400-3,500 ft, about $300 \mathrm{~m}$ above grade; clasts are angular and include those derived from the Pinto Gneiss of Miller (1938) (Xp) and white quartzite for which the nearest source is the quartzite of Pinto Mountain (Ep) $15 \mathrm{~km}$ to the southeast.

In the northeast part of the quadrangle, unconsolidated boulder gravel consists of angular to subrounded clasts of Miocene(?) flow-banded rhyolite, spherulitic rhyolite, crystal-rich (quartz-biotite-plagioclase) dacite, and friable brown quartz sandstone; possibly derived from the northern Bullion Mountains

Tvm Basalt of Valley Mountain (Miocene) - Larger patches are black, massive, nonvesicular, aphanitic, diktytaxitic olivine basanitoid of extrusive and 
intrusive origin; Bacheller (1978) reported basal alluvial sand and gravel, thin $(13 \mathrm{~cm})$ limey interbeds between flows, and a $17^{\circ}$ northeast dip. An age of $22.7 \pm 0.7 \mathrm{Ma}$ was determined by the K-Ar method on whole rock (J.K. Nakata, written commun., 1986). Also includes (as the two westernmost mapped areas) dark-green, vesicular, plagioclase-phyric, diktytaxitic basalt dikes of uncertain relation to the olivine basanitoid

Kf Felsite dikes (Late Cretaceous) - Near the Marbolite Mine in the south-central part of the quadrangle. White, microcrystalline microgranite. Contains embayed quartz phenocrysts, sparse biotite, fine-grained secondary(?) white mica, and sulfide minerals. Forms two dikes trending east-northeast. Age determined on larger dike is $71.9 \pm 1.8 \mathrm{Ma}$ on white mica by the K-Ar method (J.K. Nakata, written commun., 1985)

\section{Coxcomb Intrusive Suite}

Kcsh Sheep Hole Pass Granite (Late Cretaceous) - In the Bullion Mountains. Fineto medium-grained muscovite-biotite monzogranite. Color index about 5. Satellite pegmatite and aplite dikes are muscovite rich and contain garnet. Intrudes the metamorphosed quartz monzonite and syenogranite unit (Jbmq)

KJg Quartz-phyric granite (Cretaceous or Jurassic) - At the west-central edge of the quadrangle. Whitish, medium- to coarse-grained, muscovite-bearing, locally hornblende-bearing biotite syenogranite to monzogranite (fig. 3). Color index 3 to 7. Quartz forms medium-grained phenocrysts. Contains variable content of roundish, zoned, perthitic microcline phenocrysts 0.5 to $3 \mathrm{~cm}$ across. Primary foliation is defined by aligned mafic inclusions. Dikes and chilled pluton margin exhibit quartz and K-feldspar phenocrysts in a fine-grained matrix. Zircon is conspicuous in thin section. Thin sections show distorted and partly recrystallized grains. Some epidote is present. Forms a small pluton along the quadrangle border and another small pluton just west of the quadrangle in the same area. Cuts the diorite unit (Jd), monzonite of Twentynine Palms ( $\mathrm{kt}$ ), Dog Wash Gneiss (Xdw), and the Pinto Gneiss of Miller (1938) (Xp). Cut by mafic dikes of uncertain correlation.

Previously mapped as granodiorite by Rogers (1961), as leucocratic quartz monzonite and as medium-grained quartz monzonite by Dibblee (1968), as the White Tank unit by Bacheller (1978), and as the informally named White Tank monzogranite by Trent (1984). Resembles and may correlate to the granite of White Tank, $8 \mathrm{~km}$ to the south-southwest, that was named the White Tank monzonite by Miller (1938) and was dated by U-Pb (zircon) as $150 \mathrm{Ma}$ (Barth and others, 2008)

Jmd Mafic dikes (Jurassic) - Widespread fine- to medium-grained biotite-hornblende diorite and microdiorite dikes. Dikes commonly have chilled margins and locally show evidence of multiple intrusion and of flow sorting. Contains small amounts of quartz and pyroxene. $\mathrm{SiO}_{2}$ content of two samples is 52 and 53 percent. Rocks are altered, contain secondary epidote, and commonly are associated with bleached, epidote-enriched, iron-stained, and quartz-veined country rock. Most dikes trend north-northwest. Intrudes the granite porphyry dikes unit (Jgp) and most older rock units. Subdivided into several subunits by Woodward-McNeil and Associates (1974) in the Humbug Mountain area. 
Rocks previously mapped as propylitic andesite dikes by Hope (1966).

Suspected to correlate with the Independence Dike Swarm of Late Jurassic age (Chen and Moore, 1979; Karish and others, 1987; James, 1989; Hopson and others, 2008)

Jdu Dikes, undivided (Jurassic and Jurassic?) - Aphanitic, dark-green felsite dikes, biotite-plagioclase-phyric dikes, and unvisited dikes mapped from aerial photos

Jgp Granite porphyry dikes (Jurassic) — Fine-grained felsic dikes containing mediumto coarse-grained phenocrysts of embayed quartz, plagioclase, lavender to pink K-feldspar, biotite, and hornblende. $\mathrm{SiO}_{2}$ content of one sample 71 percent (Valley Mountain). Cuts the Virginia Dale Quartz Monzonite (Jbv). Phenocrysts closely resemble those in the Virginia Dale Quartz Monzonite

Jm Granodiorite of Music Valley (Jurassic) -Medium-grained, equigranular sphenehornblende-biotite granodiorite. Conspicuous sphene. Color index is 23; $\mathrm{SiO}_{2}$ content is 63 percent (one sample). Abundant mafic enclaves of hornblende gabbro, small (1 to $2 \mathrm{~cm}$ ) biotite clots, and softball-size microdiorite. Inclusions define a foliation concordant and subconcordant to adjacent gneiss country rock. Contains magmatic epidote and aluminous hornblende indicative of crystallization pressure on the order of $5 \mathrm{~kb}$ (E-an Zen, written and oral commun., 1985). Forms the semidiscordant Music Valley Pluton, about $5 \mathrm{~km}^{2}$ in area, southeast of Music Valley. U-Pb ion-probe dating suggests age $161 \pm 3 \mathrm{Ma}$ or a little older (Barth and others, 2008)

Jgb Granitoid rocks of Goat Basin Mine (Jurassic) - In the Gold Park area (southwest corner of the quadrangle). Intergradational granodiorite, quartz diorite, and porphyritic granite. The quartz diorite is gradational with adjacent diorite unit (Jd), and the porphyritic granite cuts the diorite. Baseball- to football-size mafic enclaves are abundant. Locally foliated. Very coarse K-feldspar and gray plagioclase phenocrysts are present in the more felsic granite and granodiorite rocks. Color index 5 to 40. Mafic minerals include biotite, hornblende, sphene, and (in quartz diorite) euhedral epidote of probable magmatic habitat. U-Pb zircon ion-probe ages $165 \pm 2 \mathrm{Ma}$ and $161 \pm 3 \mathrm{Ma}$ on two samples (Barth and others, 2008). Cuts the Pinto Gneiss of Miller (1938) (Xp) and the Dog Wash Gneiss (Xdw). Cut by aplite dikes, the mafic dikes unit (Jmd), quartz veins, and epidote veins

Jg Granite (Jurassic) - Mapped in the south-central part of the quadrangle. Mediumgrained monzogranite and leucomonzogranite; light colored on aerial photographs. Locally pegmatitic and lacking mafic minerals. Contains abundant medium- to coarse-grained quartz, purplish pink K-feldspar as large as $1.5 \mathrm{~cm}$, and greenish, saussuritized plagioclase. Mafic minerals are clotted; largely chlorite and magnetite. Grades to the Virginia Dale Quartz Monzonite (Jbv). Rocks were previously mapped as fine-grained, light-colored granitic rock by Powell (1981). Includes undivided granitoids shown in cross section

\section{Bullion Mountains Intrusive Suite}

Jbv Virginia Dale Quartz Monzonite (Jurassic) - Widespread in Pinto Mountains and Valley Mountain; similar rocks are abundant in adjacent quadrangles (Dibblee, 1968; Howard and others, 1995; Howard, 2002; Powell, 2002). 
Porphyritic magnetite-sphene-hornblende-biotite quartz monzonite and monzo-granite (fig. 3); matrix medium grained. Color index 9 to 15 ; mafics typically greenish (from secondary chlorite and epidote) and clotted. Lavender to pink, equant $\mathrm{K}$-feldspar phenocrysts, in places rimmed by white plagioclase, average $1 \mathrm{~cm}$ across $(0.5 \mathrm{~cm}$ in an area southeast of Humbug Mountain and southwest of the Virginia Dale Mine). Monzogranite on hill 2740 and hill 2700, east of Twentynine Palms Mountain and northwest of the Marbolite Mine, atypically has well-formed (not clotted) mafic minerals, gray to pink K-feldspar phenocrysts that contain unzoned inclusions of other minerals, and abundant quartz globules $0.2-0.5 \mathrm{~mm}$ in diameter. Round (locally angular) fine-grained mafic enclaves $1 \mathrm{~cm}$ across to softball size are abundant. Weathers into dark roundish outcrops and boulders. $\mathrm{SiO}_{2}$ content of four samples is 64 to 68 percent. Contains pegmatite and aplite dikes near the Marbolite Mine. Locally (near Marbolite Mine) grades to equigranular medium-grained sodic quartz diorite (tonalite; fig. 3; 56 percent $\mathrm{SiO}_{2}$ ), which in thin section reveals plagioclase grains consisting of shattered mosaics welded by interstitial K-feldspar; this texture possibly resulted from rapid decompression and pressure quenching of the magma chamber. Cut by the mafic dikes unit (Jmd) and granite porphyry dikes unit (Jgp). Cuts the diorite unit (Jd) and most older rock units. K-Ar ages $155 \mathrm{Ma}$ (biotite) and $159 \mathrm{Ma}$ (hornblende) from Valley Mountain (Calzia and Morton, 1980) and $167 \mathrm{Ma}$ (biotite) near the Marbolite Mine (Bishop, 1964). U-Pb zircon ion-probe age $167 \pm 1 \mathrm{Ma}$ (Barth and others, 2008). Rocks were previously mapped as biotiterich quartz monzonite by Dibblee (1968), as porphyritic quartz monzonite by Hope (1969), as the Chocolate Drop unit by Bacheller (1978), as porphyritic monzogranite by Powell (1981), and as porphyritic granite by Howard and Allen (1988)

Jbs Syenogranite (Jurassic) - In the Bullion Mountains. Light-colored, mediumgrained, equigranular, granophyric biotite-perthite leucosyenogranite, alkali granite, syenogranite, and quartz syenite. Locally foliated. Mafic clots are common. Includes aplite dikes. May include some bleached, altered equivalents of the quartz monzonite unit (Jbq). Pyrite and quartz veins present. Darker and finer grained near contact with limestone unit (JI) and volcanic and hypabyssal rocks unit (Jvh); the limestone unit commonly separates the syenogranite unit from the volcanic and hypabyssal rocks unit. Cataclastic near the contact with the volcanic and hypabyssal rocks unit; metamorphic foliation and lineation increase in intensity away from the volcanic and hypabyssal rocks unit

Jbq Quartz monzonite (Jurassic) - In the Bullion Mountains. Medium-grained equigranular biotite quartz monzonite and monzogranite; color index 10 to 16; locally porphyritic

Jbmq Metamorphosed quartz monzonite and syenogranite (Jurassic, protolithic age) - In the northeast corner of the quadrangle, east of the Cleghorn Lakes Fault. Gneissic, recrystallized equivalent of the quartz monzonite unit (Jbq) and syenogranite unit (Jbs). Locally strongly lineated. Heterogeneous; includes muscovite-chlorite-biotite monzogranite gneiss, sphene-biotite monzogranite gneiss, sphene-hornblende granodiorite gneiss, sparsely 
porphyritic muscovite-biotite syenogranite gneiss, and chlorite-biotite quartz monzonite gneiss. Also includes dense, gray, very fine grained syenogranite aplite dikes, hornblende alkali-granite pegmatite dikes, and bluish-gray quartz veins. Mafic minerals tend to be clotted. Metamorphism and gneissic foliation are proximal to the Sheep Hole Pass Granite (Kcsh)

Altered quartz monzonite (Jurassic) - In the Bullion Mountains, unit consists of light-colored, bleached, equigranular rocks resembling the quartz monzonite unit (Jbq), but in which primary mafic minerals are absent. Relict sphene, quartz, and feldspar, secondary calcite, epidote, and colorless amphibole are present in thin section, and epidote coatings and masses are present in outcrop. Exposure at Valley Mountain, which was not visited, has spectral signature from LANDSAT image (provided by R. Blom) that resembles signature of bleached and altered hypabyssal rocks in the Pinto Mountains east of the quadrangle (Howard and Allen, 1988)

Jvh Volcanic and hypabyssal rocks (Jurassic) - Dark rocks in three areas. In the Pinto Mountains southeast of Old Dale, consists of hypabyssal rocks containing medium-grained phenocrysts of white plagioclase, reddish-lavender Kfeldspar, and biotite in a microcrystalline groundmass. In hills north of Valley Mountain, consists of crystal-rich, possibly tuffaceous, dacite containing phenocrysts of plagioclase, biotite, hornblende, and partly resorbed quartz (volcanic rocks are also present at Valley Mountain according to Kupfer and Bassett, 1962). In the Bullion Mountains, includes porphyritic andesite, aphyric rocks, local breccia, and welded tuff containing crystals of partly resorbed quartz; structurally lowest rocks are largely welded tuff, whereas structurally higher rocks have textures suggesting hypabyssal origin; overlies or is interbedded with the limestone unit (JI) and is structurally above the syenogranite unit (Jbs); foliated and lineated; conspicuous fractures or cleavage dip shallowly northwest

Jd Diorite (Jurassic) - In the Pinto Mountains. Medium- to fine-grained, quartzbearing, biotite-hornblende diorite, quartz diorite, and gabbro. Color index 25 to 70. Locally (south-central part of the quadrangle) contains medium-grained, possibly late magmatic epidote. Igneous texture. Southwest of Music Valley, hornblende gabbro (containing pyroxene cores in hornblende) exhibits primary igneous layering. Intrudes the Pinto Gneiss of Miller (1938) (Xp), Dog Wash Gneiss (Xdw), granite of Joshua Tree (Xjt), and quartzite of Pinto Mountain (Ep, Epm). Intruded by the Virginia Dale Quartz Monzonite (Jbv) and mafic dikes unit (Jmd). Intruded by and gradational with the granitoid rocks of Goat Basin Mine (Jgb). May include bodies with a range of ages. A sample yielded a titanite $\mathrm{U}-\mathrm{Pb}$ age of $161 \mathrm{Ma}$ and a spread of $\mathrm{U}-\mathrm{Pb}$ ion-probe zircon ages, with $167 \pm 1$ Ma for a cluster of ten grains (Barth and others, 2008)

Jl Limestone (Jurassic) — In the Bullion Mountains. Tan calcitic marble about $10 \mathrm{~m}$ thick, associated hematitic skarn, and overlying thinner lenses of partly conglomeratic and arkosic quartzite. Lies above the syenogranite unit (Jbs), and at or just above the base of the volcanic and hypabyssal rocks unit (Jvh), which here consists largely of welded tuff. The contact with the syenogranite unit is parallel to foliation above and below, and the nature of the contact is 
kt Quartz monzonite of Twentynine Palms (Early Triassic) - In the southwest part of the quadrangle. Forms knobby, bouldery outcrops that weather grayish tan. Megacrystic hornblende monzonite and hornblende quartz monzonite, containing abundant equant white to buff alkali-feldspar phenocrysts 3 to 10 $\mathrm{cm}$ across. Contains accessory sphene and iron oxide. Color index about 5 to 15. Modal counts on stained slabs (fig. 3) and chemical compositions are statistically poor because of the extremely coarse grain size. $\mathrm{SiO}_{2}$ content (two samples) 61 and 67 percent. Additional modal and petrographic data presented by Barth and others (1997). Eastern exposures exhibit wavy metamorphic foliation, phenocrysts elongated west-northwest, and westward-overturned folds in common with fabric of the adjacent Dog Wash Gneiss (Xdw) and the Pinto Gneiss of Miller (1938) (Xp). On the south side of Twentynine Palms Mountain, megacryst content decreases and quartz content increases southward, and the unit may be gradational with the leucogranite gneiss south of Twentynine Palms Mountain (lgt). Intrudes the Pinto Gneiss of Miller (1938) (Xp) and is intruded by the mafic dikes unit (Jmd) and the quartz-phyric granite unit $(\mathrm{KJg})$. One kilometer west of the quadrangle, undeformed megacrystic quartz monzonite of Twentynine Palms intrudes foliated rocks of the Pinto Gneiss of Miller (1938) (Xp). Rocks were previously mapped as monzonite porphyry by Miller (1938, fig. 3), Rogers (1961), and Dibblee (1968); as part of undifferentiated Mesozoic plutonic rocks by Powell (1981); and as the informally named Twentynine Palms porphyritic quartz monzonite by Trent (1984) following the usage of Brand and Anderson (1982). U-Pb date $242 \pm 30 \mathrm{Ma}$ (Barth and others, 1997)

Igt Leucogranite gneiss south of Twentynine Palms Mountain (Mesozoic or Proterozoic) - Weathers to a light-buff color. Leucomonzogranite and leucogranodiorite gneiss containing hornblende pseudomorphs, biotite, sphene, epidote, and chlorite. Abundant quartz is present as medium- to coarse-grained irregular aggregates. Sparse coarse-grained, cream-colored, blocky K-feldspar and medium-grained, white plagioclase phenocrysts. Color index 2 to 4. Foliation is subtle to wavy; east-striking lineation is present locally. Subtle differences from the Dog Wash Gneiss (Xdw) are coarser grained quartz, less prominent foliation, presence of sphene, smaller ratio of alkali feldspar to plagioclase (fig. 3), and a possible gradational relation to the quartz monzonite of Twentynine Palms ( $\mathrm{kt}$ ). Intrudes the Pinto Gneiss of Miller (1938) (Xp) and the diorite and amphibolite unit (Xd). Cut by the mafic dikes unit (Jmd). Rocks previously mapped as part of the Palms Granite by Evans (1964) and as part of undifferentiated Mesozoic plutonic rocks by Powell (1981)

ep Quartzite of Pinto Mountain (Proterozoic) - Rocks previously mapped as the Pinto Mountain unit by Powell (1981), as supracrustal quartzite of the Joshua Tree terrane by Powell (his unit J2, 1982), and as the metasedimentary suite of Placer Canyon by Powell (1993). Called the dolomite of Iron Chief mine by Powell (2002). White and gray metaquartzite, in part crossbedded. Contains muscovite, biotite, and andalusite. Nonconformably overlies the granite of 
Joshua Tree (Xjt). A U-Pb numerical age of about 175 Ma was determined on uraninite from a vein in the quartzite unit near the Virginia Dale Quartz Monzonite (Jbv), $5 \mathrm{~km}$ southwest of the Marbolite Mine (Hewett and others, 1969; located by Calzia and Morton, 1980). Unit subdivided into subunits in the adjacent Pinto Mountain 7.5-minute quadrangle (Powell, 2002)

Epm Marble - At the stratigraphic top of the unit. Tan, buff, gray, and brown dolomitic and calcitic marble as much as about $30 \mathrm{~m}$ thick. Marble has quartzitic nodules and layers. Basal part, overlying the quartzite, is thin pelitic granofels and overlying laminated calc-silicate rock, in places replaced by massive epidote skarn. Diopside and garnet present. Skarn is associated with contact against the intrusive Virginia Dale Quartz Monzonite (Jbv)

Xgn Gneiss (Paleoproterozoic? and Paleoproterozoic) - Largely gray, fine- to mediumgrained biotite monzogranite and syenogranite gneiss. Part of unit cuts the Dog Wash Gneiss, and most of unit is cut by the Dog Wash Gneiss. On the southwest side of hill 2740 east of Twentynine Palms Mountain, includes equigranular, medium- to fine-grained, K-feldspar-rich magnetite-biotite monzogranite (age uncertain; contains fine-grained mafic enclaves $1 \mathrm{~cm}$ across) that resembles Mesozoic rocks

Xag Augen gneiss (Paleoproterozoic?) - In the southwestern part of the quadrangle. Biotite monzogranite to syenogranite gneiss containing abundant $\mathrm{K}$-feldspar augens $1 \mathrm{~cm}$ across. Color index 5 to 10 . Cuts amphibolite pods $(\mathrm{Xd})$ and the spotted gneiss unit (Xsg). $\mathrm{SiO}_{2}$ content 67 percent on one sample

Xdw Dog Wash Gneiss (Paleoproterozoic) - In the southwestern part of the quadrangle. Unit named for Dog Wash (Howard, 2002). Consists of light-buff-weathering, medium-grained leucomonzogranite to leucosyenogranite gneiss, locally trondjemitic. Color index 0.5 to 6 . Contains allanite, clotted chlorite, muscovite, oxides, and biotite. Quartz streaks separate streaks of intergrown alkali feldspar and plagioclase; possibly the streaks originated from coarse grains of quartz and perthite in the protolith. $\mathrm{SiO}_{2}$ content (one sample) 78 percent. Intrudes the Pinto Gneiss of Miller (1938) (Xp) and the diorite and amphibolite unit $(\mathrm{Xd})$. Minimum age $1.68 \mathrm{Ga}(\mathrm{U}-\mathrm{Pb}$ on zircon)(Wooden and others, 1991). Rocks previously mapped as part of the Palms Granite by Evans (1964) and as part of undifferentiated Mesozoic plutonic rocks by Powell (1981)

Xsg Spotted gneiss (Paleoproterozoic) - Mapped in the southwest corner of the quadrangle near Gold Park, on the northwest side of Twentynine Palms Mountain, and between Twentynine Palms Mountain and the Marbolite Mine. Light-gray, coarse- to fine-grained granulitic-textured feldspathic gneiss and granofels containing dark spots of chlorite+epidote+hornblende and poikiloblastic biotite. The dark spots probably are pseudomorphs of metamorphic garnet or pyroxene. Quartz blebs are bluish. Muscovite is present. Includes dark, medium- to coarse-grained biotite-rich rock spotted by white feldspars that have gray interiors. Textural resemblance to granulites suggests the unit may have experienced high-grade metamorphism before retrogression. Cuts foliated metagabbro of the diorite and amphibolite unit (Xd); adjoins and likely postdates metasedimentary granofels of the Pinto 
Gneiss of Miller (1938) (Xp). As mapped, may include metamorphosed parts of the Dog Wash Gneiss (Xdw) and the gneiss unit (Xgn)

Xjt Granite of Joshua Tree (Paleoproterozoic) - Coarse-grained and very coarse grained monzogranite and syenogranite consisting largely of megacrysts 4 to 6 $\mathrm{cm}$ across of buff-colored alkali-feldspar and lesser saussuritized plagioclase. Overlain nonconformably by the quartzite of Pinto Mountain; a paleosol at the nonconformity is described by Powell $(1981,2002)$. Powell $(1981,2002)$ reported that L.T. Silver obtained a preliminary $\mathrm{U}-\mathrm{Pb}$ minimum age on zircon of 1,650 Ma for the unit. Rocks previously mapped as the Joshua Tree granite/granite gneiss unit by Powell (1981), as map unit J1 of the Joshua Tree terrane by Powell (1982), and as the augen gneiss of Joshua Tree by Powell (1993)

Xd Diorite and amphibolite (Paleoproterozoic) - Heterogeneous diorite, foliated metadiorite, metagabbro, and amphibolite, generally associated with the Pinto Gneiss of Miller (1938) (Xp). Generally massive, but locally (lower Gold Park wash) infolded with pegmatites and other gneisses. Locally cut by the spotted gneiss unit (Xsg) and in several places by the Dog Wash Gneiss $(\mathrm{Xdw})$. Distinction from the diorite unit (Jd) is not everywhere clear. K-Ar dating on a sample from lower Gold Park wash gave numerical ages of 124 Ma on biotite, interpreted as a cooling age, and $364 \mathrm{Ma}$ on hornblende (J.K. Nakata, written commun., 1986). Rocks previously mapped as the Gold Park Gabbro-Diorite by Miller (1938), and partly mapped as the Gold Park GabbroDiorite by Evans (1964)

Xp Pinto Gneiss of Miller (1938) (Paleoproterozoic)-Dark-weathering rocks consisting of vitreous quartzitic granofels and biotite gneiss. Unit also includes arkosic metaconglomerate $1 \mathrm{~km}$ west of the quadrangle. Granofels is mostly greenish gray; contains assemblages of biotite-two feldspars, biotitegarnet-cummungtonite, garnet-biotite-sillimanite, and biotite-chloritized garnet. Muscovite-biotite-sillimanite-quartz-K-feldspar-plagioclase schist is present on Twentynine Palms Mountain and on hill 2740 to the east. Biotite gneiss may be in part orthogneiss. Some biotite-rich gneiss in southern Music Valley contains xenotime and monazite and is rich in rare-earth elements and thorium (Evans, 1964). $\mathrm{SiO}_{2}$ content of three samples is 75-82 percent.

Intruded by the Dog Wash Gneiss (Xdw) and probably by the spotted gneiss unit (Xsg) and diorite and amphibolite unit (Xd). Rocks previously mapped as the Pinto Gneiss (Miller, 1938) by Evans (1964), as granofelses (Joshua Tree terrane) by Powell (1981), and as the metasedimentary suite of Pinkham Canyon by Powell (1993) 


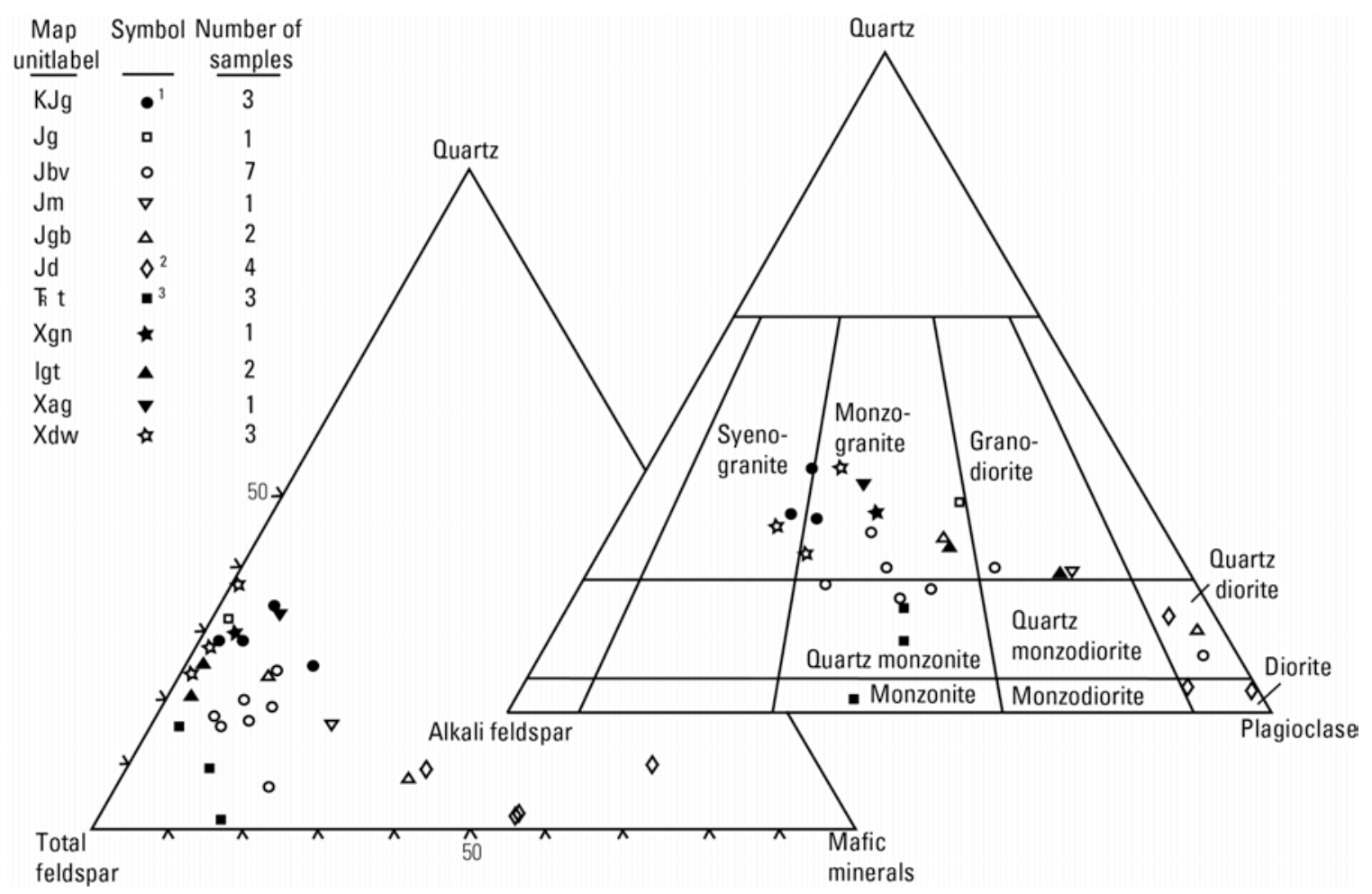

Figure 3. Modal compositions of plutonic rocks in the Valley Mountain $15^{\prime}$ quadrangle, based on counts on stained slabs. Powell (1981) listed modal counts for the granite of Joshua Tree (Xjt).

\section{References Cited}

Bacheller, John, III, 1978, Quaternary geology of the Mojave Desert-Eastern Transverse Ranges boundary in the vicinity of Twentynine Palms, California: Los Angeles, University of California, M.S. thesis, $157 \mathrm{pp}$.

Barth, A.P., Tosdal, R.M., and Wooden, J.L., 1990, A petrologic comparison of Triassic plutonism in the San Gabriel and Mule Mountains, southern California: Journal of Geophysical Research, v. 95, p. 20,075-20,096.

Barth, A.P., Tosdal, R.M., Wooden, J.L., and Howard, 1997, Triassic plutonism in southern California; Southward younging of arc initiation along a truncated continental margin: Tectonics, v. 16, p. 290-304.

Barth, A.P., Wooden, J.L., Howard, K.A., and Richards, J.L., 2008, Late Jurassic plutonism in the southwest U.S. Cordillera, in Wright, J.E., and Shervais, J.W., eds., Ophiolites, arcs, and batholiths; A tribute to Cliff Hopson: Geological Society of America Special Paper 438, p. 379-396.

Bassett, A.M., and Kupfer, D.H., 1964, A geologic reconnaissance in the southeastern Mojave Desert, California: California Division of Mines and Geology, Special Report $83,43 \mathrm{p}$. 
Bishop, C.C., 1964, Needles sheet: California Division of Mines and Geology, Geologic map of California, Olaf P. Jenkins Edition, scale 1:250,000.

Brand, J.H., and Anderson, J.L., 1982, Mesozoic alkalic monzonites and peraluminous adamellites of the Joshua Tree National Monument, southern California: Geological Society of America Abstracts with Programs, v. 14, no. 4, p. 151-152.

Calzia, J.P., and Morton, J.L., 1980, Compilation of isotopic ages within the Needles $1^{\circ}$ by $2^{\circ}$ quadrangle, California and Arizona: U.S. Geological Survey Open-File Report $80-1303$.

Carter, J.N., Luyendyk, B.P., and Terres, R.R., 1987, Neogene clockwise rotation of the eastern Transverse Ranges, California, suggested by paleomagnetic data: Geological Society of America Bulletin, v. 98, p. 199-206.

Chen, J.H., and Moore, J.G., 1979, Late Jurassic Independence dike swarm in eastern California; Geology, v. 7, p. 129-133.

Dibblee, T.W., Jr., 1961, Evidence of strike-slip movement on northwest-trending faults in Mojave Desert, California, in Geological Survey Research 1961: U.S. Geological Survey Professional Paper 424-B, p. 197-199.

Dibblee, T.W., Jr., 1967, Evidence of major lateral displacement on the Pinto Mountain Fault, southeastern California: Geological Society of America Abstracts for 1967, Special Paper 115, p. 322.

Dibblee, T.W., Jr., 1968, Geologic map of the Twentynine Palms quadrangle, San Bernardino and Riverside Counties, California: U.S. Geological Survey Miscellaneous Geologic Investigations Map I-561, scale 1:62,500.

Dokka, R.K., and Travis, C.J., 1990, Late Cenozoic strike-slip faulting in the Mojave Desert, California: Tectonics, v. 9, p. 311-340.

Evans, J.R., 1964, Xenotime mineralization in the southern Music Valley area, Riverside County, California: California Division of Mines and Geology Special Report 79, 24 p.

Frizzell, V.A., Jr., Mattinson, J.M., and Matti, J.C., 1986, Distinctive Triassic megaporphyritic monzogranite; Evidence for only $160 \mathrm{~km}$ offset along the San Andreas Fault, southern California: Journal of Geophysical Research, v. 91, p. 14,080-14,088.

Hewett, D.F., Stone, Jerome, and Stieff, L.R., 1969, The ages of three uranium minerals, Mojave Desert, California, in Geological Survey Research 1969: U.S. Geological Survey Professional Paper 650-B, p 84-88.

Hope, R.A., 1966, Geology and structural setting of the eastern Transverse Ranges, southern California: Los Angeles, University of California, Ph.D. dissertation, 158 p.

Hope, R.A., 1969, The Blue Cut Fault, southeastern California, in Geological Survey Research 1969: U.S. Geological Survey Professional Paper 650-D, p. D116-D121.

Hopson, R.F., 1997, Basement rock geology and tectonics of the Pinto Mountain Fault, Sand Bernardino County, southern California: Los Angeles, California State University, M.S. thesis, 134 p.

Hopson, R.F., 1998, Quaternary geology and neotectonics of the Pinto Mountain Fault, Mojave Desert, southern California: California Geology, v. 51, no. 6, p. 3-13.

Hopson, R.F., Hillhouse, J.W., and Howard, K.A., 2008, Dike orientations in the Late Jurassic Independence dike swarm and implications for vertical axis tectonic rotations 
in eastern California, in Wright, J.E. and Shervais, J.W., eds., Ophiolite, arcs, and batholiths: Geological Society of America Special Paper 438, p. 481-498.

Howard, K.A., 2002, Geologic map of the Sheep Hole Mountains 30' x 60' quadrangle, San Bernardino and Riverside Counties, California: U.S. Geological Survey map MF2344, 2 sheets, scale 1:100,000. (Available at ://pubs.usgs.gov/mf/2002/2344/.)

Howard, K.A., and Allen, C.M., 1988, Geologic map of the southern part of the Dale Lake 15-minute quadrangle, San Bernardino and Riverside Counties, California: U.S. Geological Survey Open-File Report 88-534, 17 p., scale 1:62,500.

Howard, K.A., and John, B.E., 1984, Geologic map of the Sheep Hole-Cadiz Wilderness Study Area (CDCA-305), San Bernardino County, California: U.S. Geological Survey Miscellaneous Field Studies Map MF-1615-A, scale 1:62,500.

Howard, K.A., and Miller, D.M., 1992, Late Cenozoic faulting at the boundary between the Mojave and Sonoran blocks, Bristol Lake area, California, in Richard, S.M., ed., Deformation associated with the Neogene eastern California shear zone, southeastern California and southwestern Arizona: Redlands, Calif., San Bernardino County Museums Special Publication 92-1, p. 37-47.

Howard, K.A., Hopson, R.F., Hagai, R., and Nur, A., 1997, Vertical axis rotations in the Mojave; Evidence from the Independence Dike Swarm; Comment and Reply: Geology, v. 25, p. 1051-1052.

Howard, K.A., Jagiello, K.J., Fitzgibbon, T.T., and John, B.E., in press, Geologic map of the Lead Mountain 15' quadrangle, San Bernardino County, California: U.S. Geological Survey General Quadrangle Map GQ-1766, scale 1:62,500.

Jagiello, Keith, Christie, J.M., and Blom, R.G., 1992, Horizontal separation of major late Cenozoic strike-slip faults in the Twentynine Palms region, Mojave Desert, California, in Richard, S.M., ed., Deformation associated with the Neogene eastern California shear zone, southeastern California and southwestern Arizona: Redlands, Calif., San Bernardino County Museums Special Publication 92-1, p. 48-53.

James, E.W., 1989, Southern extension of the Independence dike swarm of eastern California: Geology, v. 17, p. 587-590.

Karish, C.R., Miller, E.L., and Sutter, J.F., 1987, Mesozoic tectonic and magmatic history of the central Mojave Desert, in Dickinson, W.R., and Klute, M.A., eds., Mesozoic rocks of southern Arizona and adjacent areas: Arizona Geological Society Digest, v. 18 , p. 15-32.

Kupfer, D.H., and Bassett, A.M., 1962, Geologic reconnaissance map of part of the southeastern Mojave Desert, California: U.S. Geological Survey Mineral Investigations Field Studies Map MF-205, scale 1:125,000.

Mariano, John, Helferty, M.G., and Gage, T.B., 1986, Bouger and isostatic residual gravity maps of the Colorado River region, including the Kingman, Needles, Salton Sea, and El Centro quadrangles: U.S. Geological Survey Open-File Report 86-347, scale $1: 250,000,7$ sheets.

Miller, W.J., 1938, Pre-Cambrian and associated rocks near Twentynine Palms, California: Geological Society of America Bulletin, v. 49, p. 417-446. 
Moyle, W.R., Jr., 1961, Data on water wells in the Dale valley area, San Bernardino and Riverside Counties, California: California Department of Water Resources Bulletin 91$5,55 \mathrm{p}$.

Postlethwaite, C.E., 1988, The structural geology of the Red Cloud thrust system, southern eastern Transverse Ranges, California: Ames, Iowa, Iowa State University, Ph.D. dissertation.

Powell, R.E., 1981, Geology of the crystalline basement complex, eastern Transverse Ranges, southern California; Constraints on regional tectonic interpretation: Pasadena, California, California Institute of Technology, Ph.D. dissertation, 441 p.

Powell, R.E., 1982, Crystalline basement terranes in the southern eastern Transverse Ranges, California, in Cooper, J.D., comp., Geologic excursions in the Transverse Ranges, southern California: Geological Society of America, Cordilleran Section 78th Annual Meeting, Anaheim, California, April 19-21, 1982, Volume and guidebook, p. 109-151.

Powell, R.E., 1993, Balanced palinspastic reconstruction of pre-late Cenozoic paleogeology, southern California: Geologic and kinematic constraints on evolution of San Andreas Fault system, in Powell, R.E., Weldon, R.J., II, and Matti, J.C., eds., The San Andreas Fault system: Displacement, palinspastic reconstruction, and geologic evolution: Geological Society of America Memoir 178, p. 1-106.

Powell, R.E., 2002, Geologic map and digital database of the Pinto Mountain 7.5 minute quadrangle, Riverside County, California: U.S. Geological Survey Open-File Report 02-491, 34 p., scale 1:24,000. (Available at http://geopubs.wr.usgs.gov/open-file/of02491.)

Rogers, J.J.W., 1961, Igneous and metamorphic rocks of the western portion of Joshua Tree National Monument, Riverside and San Bernardino Counties, California: California Division of Mines, Special Report 68, p. 7-26.

Trent, D.D., 1984, Geology of the Joshua Tree National Monument, Riverside and San Bernardino Counties: California Geology, v. 37, no. 4, p. 75-86.

U.S. Geological Survey, 1981, Aeromagnetic map of the Needles $1^{\circ}$ by $2^{\circ}$ quadrangle, California and Arizona: U.S. Geological Survey Open-File Report 81-85, scale $1: 250,000$.

Wooden, J.L., and Miller, D.M., 1990, Chronologic and isotopic framework for Early Proterozoic crustal evolution in the eastern Mojave Desert region, southeastern California: Journal of Geophysical Research, v. 95, p. 20,133-20,146.

Wooden, J.L., Powell, R.E., Howard, K.A., and Tosdal, R.M., 1991, Eagle Mtns. 30' x 60' quadrangle, southern California; II Isotopic and chronologic studies: Geological Society of America Abstracts with Programs, v. 23, no. 5, p. A478.

Woodward-McNeil and Associates, 1974, The Pinto Mountain Fault at Humbug Mountain, California, in Southern California Edison Company, Information concerning site characteristics, Vidal Nuclear Generating Station: Southern California Edison Company, v. V, appendix 2.5-E, fig. E-16, scale 1:24,000 (approx.). 